Abstracta Iranicacta Iranica

Revue bibliographique pour le domaine irano-aryen

Volume 26 | 2005

Comptes rendus des publications de 2003

\title{
"The Secular Judicial System in Safavid Persia ». St. Ir., 29/1 (2000), pp. 9-60.
}

\section{Rudi Matthee}

\section{(2) OpenEdition}

1 Journals

\section{Édition électronique}

URL : http://journals.openedition.org/abstractairanica/2747

DOI : 10.4000/abstractairanica.2747

ISSN : 1961-960X

Éditeur :

CNRS (UMR 7528 Mondes iraniens et indiens), Éditions de l'IFRI

\section{Édition imprimée}

Date de publication : 15 mai 2005

ISSN : 0240-8910

\section{Référence électronique}

Rudi Matthee, « «The Secular Judicial System in Safavid Persia ». St. Ir., 29/1 (2000), pp. 9-60. », Abstracta Iranica [En ligne], Volume 26 | 2005, document 225, mis en ligne le 08 décembre 2005, consulté le 25 septembre 2020. URL : http://journals.openedition.org/abstractairanica/2747 ; DOI https://doi.org/10.4000/abstractairanica.2747

Ce document a été généré automatiquement le 25 septembre 2020.

Tous droits réservés 


\section{"The Secular Judicial System in}

\section{Safavid Persia ». St. Ir., 29/1 (2000), pp. 9-60.}

\section{Rudi Matthee}

1 The author offers a comprehensive overview of the judicial system as it operated in Safavid Iran. The first part discusses the long-standing tradition of direct appeal to the shah and how it evolved in the Safavid period. This is followed by an examination of the role and function of the divanbegi and other judicial officers. The last part of the article is devoted to various aspects of the judicial system such as court proceedings, the quality of justice, various types of punishment, and the nature of justice in the provinces. The author also pays attention to justice administered by the religious forces and secular justice, and rightfully argues that the former was really an extension of the latter. He concludes that, in spite of some major changes - such as the growing prominence of the divanbegi - the system showed remarkable continuity and stability and above all was designed to help maintain the status quo.

\section{INDEX}

Thèmes : 4.2.1. Safavides et Qâjârs 
AUTEURS

RUDI MATTHEE

University of Delaware 